\title{
Control of the Two-Spotted Spider Mite, Tetranychus urticae Koch on Kidney Bean and Pea Plants
}

\author{
A. A. Abdallah*; M. M. Al-Azzazy*; M. H. Mowafi*; E. M. A. El-Saiedy** and M. A. Pastawy* \\ "Agric. Zoology and Nematology Dept. Fac. of Agric., Al - Azhar Univ., Cairo, Egypt \\ ${ }^{* *}$ Plant Protection Dept., National Research Centre, Dokki, Giza, Egypt
}

\begin{abstract}
The effect of the two predatory mite species Phytosiulus persimilis Athias-Henriot and Typhlodromips swirskii (AthiasHenriot), fungal entomopathogen, Beuvaria bassiana and the biochemical compound Abamectin (Vapcomic) were investigated against the two-spotted spider mite, Tetranychus urticae Koch on kidney bean (Paulista) and sugar snap pea (Snow wind) in a greenhouse at Behaira governorate during 2013 season. The average number of spider mite population was significantly different among the different treatments on Paulista $\left(F_{4,99}=39.025 ; P<0.001\right.$; Table 1$)$, and on Snow wind $\left(F_{4,99}=32.17 ; P<0.001\right)$. The mean reduction percentage of spider mite populations on both plant varieties by $P$. persimilis was significantly the highest (95.2\%), followed by treating with Vapcomic (90.0\%) and the fungus $B$. bassiana (84.8\%); T. swirskii caused the least (71.9\%). Thus, using P. persimilis to control the two spotted spider mite on the two plant varieties (Paulista and Snow wind) is recommended.
\end{abstract}

Key Words: Tetranychus urticae, Phytosiulus persimilis, Typhlodromips swirskii, Beuvaria bassiana, Vapcomic.

\section{INTRODUCTION}

Bean, Phaseolus vulgaris L. and Pea, Pisum sativum L. are the most important economic vegetable crops in Egypt for both local consumption and export.

The two spotted spider mite, Tetranychus urticae Koch is one of the most important pests of many horticultural and field crops and attacks more than 200 host plant species.

The intensive use of insecticides and acaricides has led to resistance in many insect and mite species (van Leeuwen et al., 2010). Therefore, there has been an increasing interest in controlling spider mites by alternative control tactics such as biological control agents. The phytoseiid mite, Phytoseiulus persimilis is a specialist predator feeding on Tetranychus species (McMurtry and Croft, 1997). As considered its most frequent biological control agent especially in greenhouses (van Lenteren and Woets, 1988).

The predatory mite Typhlodromips swirskii (Athias-Henriot) is a generalist predator known to feed on other pests, e.g. whitefly, thrips and lepidopteran eggs (Swirski et al., 1967; Ragusa and Swirskii, 1975; Hoda et al., 1986; McMurtry and Croft, 1997). It is a recent addition to the beneficial assortment, developed and marketed by the Dutch producer of beneficial, Koppert B.V. (van Houten et $a l ., 2005)$. It is capable to prey on spider mites (Swirski et al., 1967; El-Laithy and Fouly, 1992; Momen and El-Saway, 1993; van Houten et al.,
2007).

The use of entomopathogenic fungi to control certain pests may be an alternative for solving problems of chemical resistance (Omoto et al., 1994) and environmental contamination, thereby improving the economical and biological sustainability of this agro-ecosystem (Alves et al., 2005). Beauveria bassiana (Balsamo) is one of the major entomopathogen fungal (Rashki et al., 2009). It is widely distributed in nature (St. Leger et al., 1992) and has been formulated for application in agricultural insect pest management systems with successful results (Wright and Kennedy, 1996; Faria and Wraight, 2001; Inglis et al., 2001; Feng et al., 2004) and also has potential for mite control (Irigaray et al., 2003; Wekesa et al., 2006; Maniania et al., 2008).

It has been estimated that the spider mite, $T$. urticae has evolved resistance to more than 80 acaricides to date (Knowles, 1997; Devine et al., 2001; Choi et al., 2004; Van Pottelberge et al., 2008 and 2009) and resistance has been reported from many countries. As for mechanisms of resistance to acaricides with new modes of action (e.g. Abamectin, fenpyroximate, chlorphenapyr, METI-acaricides, spirodiclofen) enhanced detoxification in T. urticae strains has been reported (Devine et al., 2001; Stumpf and Nauen 2001and 2002; Kim et al., 2004a and b; Van Leeuwen et al., 2006; Van Pottelberge et al., 2008 and 2009).

The present study aims to control the phytophagous mite, T. urticae on plants by using two 
predatory mite species, $P$. persimilis, and $T$. swriskii and the entomopathogenic fungi B. bassiana as well as Abamectin.

\section{MATERIALS AND METHODS}

\section{Experimental design:}

The two plant species, kidney bean "Paulista" and the sugar snap pea "Snow wind" were cultivated in a greenhouse to study the control of the spider mite, $T$. urticae by using two predatory mite species, on entomopathogenic fungi and a chemical compound at Nubariya, El-Behaira governorate in 2013. Five treatments for each plant species were conducted; each treatment was replicated three times. The experimental design was complete randomized block. In order to study the population of phytophagous species, leaf samples were collected weekly, starting on 22th Septmber 2013 until 2nd February 2014.

\section{Sampling Procedure:}

Twenty leaves of each treatment were randomly collected from the two plant species, placed directly into plastic bags and transported to the laboratory. All mite stages were counted to evaluate the reduction percentage of the pest populations on the cultivars after treated.

\section{Rearing the predatory mites:}

The predatory mites, $P$. persimilis and $T$. swirskii were reared using the methods modified by McMurtry and Scriven (1965); large plastic boxes 26 $\mathrm{x} 15 \times 10 \mathrm{~cm}$ were used. Cotton pad was placed in the middle of each box, leaving a space provided with water as a barrier to prevent predatory mites from escaping. Excised bean leaves highly infested with $T$. urticae were provided every day as a food source and the plastic boxes were kept in an incubator at $25 \pm 2$ ${ }^{\circ} \mathrm{C}$.

\section{Mass rearing the predatory mites:}

For mass rearing of the predatory mites, bean plant, $P$. vulgaris was served as host plant which reared in a small glasshouse divided into three isolated parts (a) clean bean plants, (b) clean plants at stage of 12 leaves infested with spider mite, T. urticae (c) bean plants infested with five gravid females of the predatory mites for every plant (El-Saiedy, 2003 and El-Saiedy and Romeih, 2007). Temperature in the glasshouse ranged from 18 to $25^{\circ} \mathrm{C}$ and relative humidity from $50-60 \%$.

\section{Release of Predatory mites:}

The predatory mite species: $P$. persimilis, was released on $22^{\text {th }}$ of September as the population density of $T$. urticae build up on two plant species with a rate of $1: 7$ predatory mite/prey, respectively for one time. The second predatory mite species, $T$. swirskii was released two times on $22^{\text {th }}$ of September and repeated again on $27^{\text {th }}$ of October. Repetitions of releasing samples were conducted weekly. Both mite pest and predatory mite individual were calculated.

\section{Other control type:}

B. bassiana Anti-Insect $\odot$ was sprayed three times (on $22^{\text {th }}$ of September, $27^{\text {th }}$ of October and on $1^{\text {st }}$ of December) at a rate of $1 \mathrm{~L} / 100$ Liters water.

The chemical compounds: Vapsomic (Abamectin) was used three times at a rate of $40 \mathrm{Cm} 3 / 100$ Liters water $+250 \mathrm{~cm} 3$ oil kaby.

The reduction percentages of the average population number of phytophagous species were calculated according to the equation of Henderson and Titton, 1955).

\section{Statistical analysis:}

One-way analysis of variance (ANOVA) and mean comparison using Fisher's least significant difference (LSD) were conducted for the number of spider mite, using the software packages SPSS 16.0.0 (USA) for windows. Significance level was $\mathrm{P} \leq 0.05$.

\section{RESULTS AND DISCUSSION}

The two predatory species, $P$. persimilis and $T$. swriskii; the biochemical compound Abamectin (Vapcomic) and the entomopathogen fungal $B$. bassiana were used to evaluate their effect in reducing the population densities of the two spotted spider mite, T. urticae on kidney bean "Paulista" and the sugar pea "Snow wind".

The control experiments were started on both plant hosts from the $4^{\text {th }}$ week of germination when the infestation of the two plant species with $T$. urticae started. The average number of spider mite was about the same on both plant species (about 40 individuals/compound leaf, on $22^{\text {nd }}$ of September then the experiments started).

Table 1 showed that the average number of spider mite and the reduction percentage for all treatments, on each of Paulista and Snow wind.

For Paulista: There was high significant difference between the average number of spider mite populations of the different treatments on Paulista $\left(F_{4,99}=39.025 ; P<0.001\right) . P$. persimilis and the Vapcomic treatments gave the highest reduction percentage of spider mite population $94.9 \%$ (with 13.15individual/leaf) and $92.2 \%$ (with 19.81individuals/leaf), respectively. The fungus treatment caused $86.3 \%$ (with 35.03 individuals/leaf); while T. swriskii gave the lowest reduction percentage of spider mite population $68.5 \%$ (with 
Table 1: The population average of spider mite, T. urticae / leaf and their corresponding reduction percentage by the two predatory mite species, fungus and Vapcomic on the two plant hosts.

\begin{tabular}{|c|c|c|c|c|c|c|c|c|c|}
\hline \multirow{3}{*}{ Treatments } & \multicolumn{8}{|c|}{ Plant species } & \multirow{3}{*}{$\begin{array}{c}{ }^{*} \text { Mean } \\
\text { Reduction } \\
\%\end{array}$} \\
\hline & \multicolumn{4}{|c|}{ Paulista } & \multicolumn{4}{|c|}{ Snow wind } & \\
\hline & Mean \pm SE & Max. & Min. & Reduction & Mean \pm SE & Max. & Min. & Reduction & \\
\hline T. swirskii & $80.30 \pm 5.67^{\mathrm{c}}$ & 129.25 & 43.95 & 68.5 & $61.18 \pm 4.24^{\mathrm{c}}$ & 48.10 & 18.10 & 75.2 & 71.9 \\
\hline P. persimilis & $13.15 \pm 3.99^{\mathrm{a}}$ & 44.05 & 0.00 & 94.9 & $11.20 \pm 1.66^{\mathrm{a}}$ & 21.50 & 0.00 & 95.5 & 95.2 \\
\hline Fungus & $35.03 \pm 5.78^{b}$ & 91.55 & 8.70 & 86.3 & $41.34 \pm 9.75^{\mathrm{b}}$ & 73.75 & 1.75 & 83.3 & 84.8 \\
\hline Vapcomic & $19.81 \pm 4.42^{\mathrm{ab}}$ & 62.25 & 1.50 & 92.2 & $30.13 \pm 6.22^{b}$ & 45.75 & 1.25 & 87.8 & 90.0 \\
\hline Control & $255.30 \pm 37.92^{d}$ & 511.80 & 43.95 & - & $247.08 \pm 39.08^{\mathrm{d}}$ & 258.70 & 21.00 & - & - \\
\hline
\end{tabular}

"Mean reduction is the reduction of both treatments of the plant species. Means followed by different subscript letters within columns are significantly different from each other $(\mathrm{P}<0.05)$ LSD test.

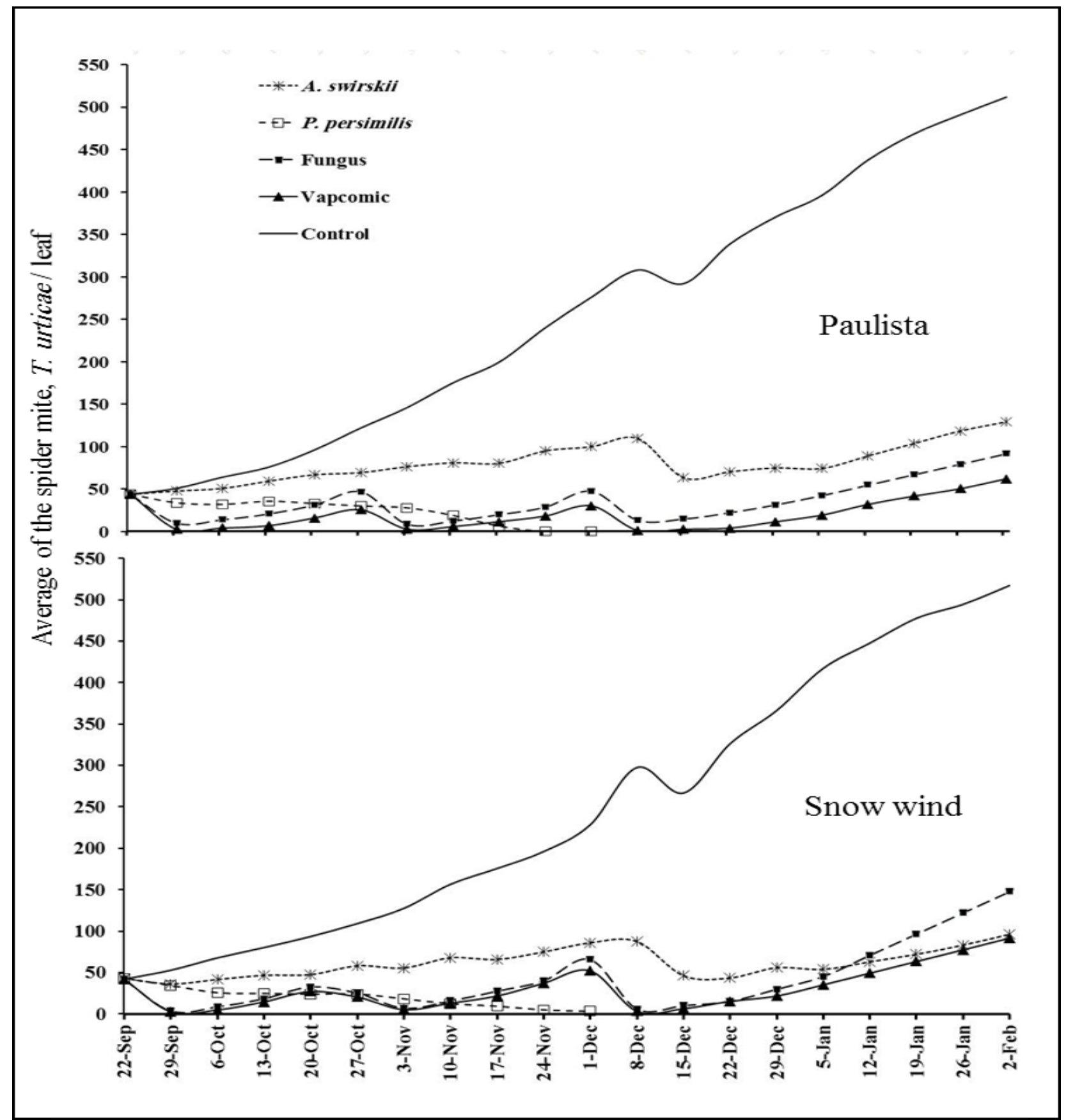

Fig. (1): The average number of the spider mite, T. urticae/leaf, week on the two plant species affected by releasing the two predatory mite species, fungus, and Vapcomic as well as the control. 
80.30 individuals/leaf).

For Snow wind: There was a high significant differences of between average numbers of spider mite population when using the four treatments and compared with the control $\left(F_{4,99}=32.17 ; P<0.001\right)$. $P$. persimilis gave the highest reduction percentage of the pider mite population $95.5 \%$ (with 11.20 individuals/leaf; $P<0.05$ ), followed by the Vapcomic and the fungus treatments which were $87.8 \%$ (30.13 individuals/leaf) and $83.3 \%$ (with 41.34 individuals/ leaf), respectively; while $T$. swriskii caused the lowest reduction percentage of spider mite population among all treatments $75.2 \%$ (with 61.18 individuals/ leaf; $P<0.05$ (Table 1).

Figure 1 summarizes the relation between time (week) and the mean average numbers of the spider mite (individuals) for the previously mentioned four treatments and the control for each of the two plant species.

The $P$. persimilis treatment curve was approximately consent for the first five weeks from the beginning of the experiment, then decreased and reaching approximately the zero value through the next three weeks and then continued at the zero value for the rest of the season (Fig.1).

The curves of the Vapcomic and fungus treatments revealed the same trend. For each of the two curves a sharp decrease was noted in spider mite population for one week after the first spraying on $22^{\text {th }}$ of September. This decrease followed by a slight increase till the population reached its first peak after 5 weeks. The second spraying was carried out on $27^{\text {th }}$ of October. For five weeks after the $2^{\text {nd }}$ spraying, the spider mite population had the same cycle as that of $1^{\text {st }}$ five weeks. After 10 weeks the $3^{\text {rd }}$ spraying was carried out (on $1^{\text {st }}$ of December). Whenever the spider mite population decreased sharply for one week then started to increase which continued till the end of the season.

For T. swirskii treatment, the spider mite population decreased significantly compared with that of the control. The spider mite population increased till the second release (on $8^{\text {th }}$ of December, after which the spider mite population sharply decreased for one week due to the weather conditions. After that, the spider mite population remained constant for the next 3 weeks after which the population started to increase and this increase continued till the end of the season at which the population reached 129.25 individuals/ leaf (Fig.1).

For the curve which represents the control of both plant species; there was no significant difference of spider mite population on both plant hosts $\left(F_{9,199}=\right.$ 31.50; $P<0.05)$. Figure 1 indicates that the spider mite population gradually increased for both treatments till reached its first peak (about 300 individuals/ leaf), at the eleventh week (on $8^{\text {th }}$ of September). Through the next week, the spider mite population decreased in both plant species due to the weather condition, after which the spider mite started to increase again and this increase continued till the end of the season at which the population reached about 500 individuals/ leaf.

Several species of natural enemies have been reported to prey on T. urticae and studies have been conducted in different countries to assess the effect and potential of natural enemies for controlling the pest without the use of pesticides (Garcia-Mari and Gonzalez-Zamora, 1999). The entomopathogenic fungi play an important role in the regulation of phytophagous mite populations and sometimes to decimate it (Van der Geest et al., 2000) and consequently reduce the application of acaricides. So the biological control by the fungi is much more economical than chemical control. Successful biocontrol can be obtained in many cases (e.g. Brødsgaard and Enkegaard, 1997; Messelink et al., 2005\& 2006).

The predatory mite, $P$. persimilis enhanced the lowest population number of spider mite, $T$. urticae 13.15individuals for Paulista and 11.20 individuals/ leaf for Snow wind. The predatory mite $P$. persimilis was efficient to suppress the spider mite populations. These results agree with that of Gould (1971); French et al. (1976) and Mori \& Saito (1979) which suggested $P$. persimilis type I as a specialist predator of all species of genus Tetranychus (McMurtry and Croft, 1997); and could provide the best control of this pest. Table 1 shows that the reduction percentage of spider mite populations by the predatory mite, $P$. persimilis was significantly the highest LSD; $P<$ $0.01 ; 94.9 \%$ for Paulista and $95.5 \%$ for Snow wind (the mean reduction percentage for the two plant species averaged $95.2 \%$. Also, the mean reduction percentages for the other treatments are $90.0 \%$ for Vapcomic, $84.8 \%$ for B. bassiana and $71.9 \%$ for $T$. swirskii.

As there is no significant difference between population reduction of spider mite when using each of $P$. persimilis and Vapcomic treatments Paulista, $P$. persimilis is more preferable to control spider mite than Vapcomic as a biochemical compound control requires 3 applications through the season; while application of $P$. persimilis requires only one release per season. 


\section{REFERENCES}

Alves, S.B; Tamai, M.A.; Rossi, L.S. and Castiglioni, E. 2005. Beauveria bassiana pathogencity to the citrus rust mite Phyllocoptruta olivora. Exp. Appl. Acarol., 37:117-122.

Brødsgaard, H.F. and Enkegaard, A. 1997. Interactions among polyphagous anthocorid bugs used for thrips control and other beneficials in multi-species biological pest management systems. In: Pandalai SG, editor. Research Signpost, Trivandrum. Recent Research Development in Entomology, 153-160.

Choi, W.I.; Lee, S.G.; Park, H.M. and Ahn, Y.J. 2004. Toxicity of plant essential oils to Tetranychus urticae (Acari: Tetranychidae) and Phytoseiulus persimilis (Acari: Phytoseiidae). J. Econ. Entomol., 97:553-558

Devine, G.J.; Barber, M. and Denholm, I. 2001. Incidence and inheritance of resistance to METIacaricides in European strains of the two-spotted spider mite (Tetranychus urticae) (Acari: Tetranychidae). Pest Manag. Sci., 57:443-448.

El-Laithy, A.Y.M. and Fouly, A.H. 1992. Life table parameters of the two phytoseiid predators Amblyseius scutalis (Athias-Henriot) and $A$. swirskii A.-H. (Acari, Phytoseiidae) in Egypt. Journal of Applied Entomology, 113(1): 8-12.

El-saiedy, E.M.A. 2003. Integrated control of red spider mite Tetranychus urticae Koch on strawberry plants. Ph.D. Thesis, Fac. Agri., Cairo Univ., 171PP.

El-saiedy, E.M.A. and Romeih, H.M. 2007. Comparative studies between predatory mites and pesticides in controlling Tetranychus urticae Koch on strawberry plants at Qualubyia Governorate. J. Agri. Sci., Mansoura Univ., 32(4): 2601- 2608.

Faria, M. and Wraight, S.P. 2001. Biological control of Bemisia tabaci with fungi. Crop Prot., 20:767-778.

Feng, M.G.; Pu, X.Y.; Ying, S.H. and Wang, Y. 2004. Field trials of an oil-based emulsifiable formulation of Beauveria bassiana conidia and low application rates of imidacloprid for control of false-eye leafhopper, Empoasca vitis, in Southern China. Crop Prot., 23:489-496.

French, N.; Parr, W.J.; Gould, H.J.; Williams, J.J. and Simmonds, S.P. 1976. Development of biological methods for the control of Tetranychus urticae on tomatoes using Phytoseiulus persimilis. Ann. Appl. Biol., 83: 177-189.

Garcia-Mari, F. and Gonzalez-Zamora, J. E. 1999. Biological control of Tetranychus urticae (Acari: Tetranychidae) with naturally occurring predators in strawberry plantings in Valencia, Spain. Exp. Appl. Acarol., 23: 487-495.

Gould, H.J. 1971. Large-scale trials of an integrated control programme for cucumber pests on commercial nurseries. Plant Path., 20:149-156.

Henderson, C.E. and Tilton, E.W. 1955. Tests with acaricides against the brown wheat mites. J. Econ. Entomol., 84: 157-161.
Hoda, F. M.; El-Naggar, M. E.; Taha, A. H. and Ibrahim, G. A. 1986. Effect of different types of food on fecundity of predacious mite Amblyseius swirskii Athias- Henriot (Acari: Phytoseiidae). Bull. Soc. Ent. Egypte, 66: 113-116.

Inglis, G.D.; Goettel, M.S.; Butt, T.M. and Strasser, H. 2001. Use of Hyphomycetous fungi for managing insect pests. In: Butt TM, Jachsonand C, Magan N (eds) Fungi as biocontrol agents: Progress problems and potential. CABI Publishing, Wallingford, pp 23-69.

Irigaray, F.J.S.; Marco-Mancebo'n, V. and Pe'rezMoreno, I. 2003. The entomopathogenic fungus Beauveria bassiana and its compatibility with triflumuron: effect on the two spotted spider mite, Tetranychus urticae. Biol. Control, 26:168-173.

Kim, H.K.; Kim, J.R. and Ahn, Y.J. 2004. Acaricidal activity of cinnamaldehyde and its congeners against Tyrophagus putrescentiae (Acari: Acaridae). J. Stored Prod. Res., 40:55-63.

Kim, Y.J.; Lee, S.H.; Lee, S.W. and Ahn, Y.J. 2004. Fenpyroximate resistance in Tetranychus urticae (Acari: Tetranychidae): cross-resistance and biochemical resistance mechanisms. Pest Manag. Sci., 60: 1001-1006.

Knowles, C.O. 1997. Mechanisms of resistance to acaricides. In: Sjut V (ed) Molecular mechanisms of resistance to agrochemicals, vol 13. Springer, Berlin, pp 57-77.

Maniania, N.K.; Bugeme, D.M.; Wekesa, V.W.; Delalibera, I.J.R. and Knapp, M. 2008. Role of entomopathogenic fungi in the control of Tetranychus evansi and Tetranychus urticae (Acari: Tetranychidae), pests of horticultural crops. Exp. Appl. Acarol., 46:259-274.

McMurtry, J.A. and Croft, B.A. 1997. Life-styles of phytoseiid mites and their roles in biological control. Annu Rev Entomol., 42:291-321.

McMurtry, J.A. and Scriven, G.J. 1965. Insectory production of Phytoseiulus persmilis. J. Econ. Entomol., 58, 282- 284.

Messelink, G.; van Steenpaal, S. and van Wensveen, W. 2005. Typhlodromips swirskii (AthiasHenriot) (Acari: Phytoseiidae): a new predator for thrips control in greenhouse cucumber. IOBC/wprs Bulletin 28(1): 183-186.

Messelink, G.J.; van Steenpaal, S.E.F. and Ramakers. M.J. 2006. Evaluation of phytoseiid predators for control of western flower thrips on greenhouse cucumber. Biocontrol, 51(5): 753- 768.

Momen, F.M. and El-Saway, S.A. 1993. Biology and Feeding-Behavior of the Predatory Mite, Amblyseius-Swirskii (Acari, Phytoseiidae). Acarologia, 34(3): 199-204.

Mori, H. and Saito, Y. 1979. Biological control of Tetranychus urticae Koch (Acarina: Tetranychidae) populations by three species of phytoseiid mites (Acarina: Phytoseiidae). J. Fac. Agric. Hokkaido Univ., 59: 303-311.

Omoto, C.; Dennehy, T.J.; McCoy, C.W.; Crane, S.E. and Long, J.W. 1994. Detection and characterization of the interpopulation variation of citrus rust mite (Acari: Eriophyidae) resistance to 
dicofol in Florida citrus. J. Econ. Entomol., 87:566-572.

Ragusa, S. and Swirski, E. 1975. Feeding habits, development and oviposition of the predacious mite Amblyseius swirskii Athias-Henriot (Acarina: Phytoseiidae) on pollen of certain weeds. Israel Journal of Entomology, 10: 93-103.

Rashki, M.; Kharazi-pakdel, A.; Allahyari, H. and van Alphen, J.J.M. 2009. Interaction among the entomopathogenic Tetranychus urticae fungus, Beauveria bassiana (Ascomycota: Hypocreales), the parasitoid, Aphidius matricariae (Hymenoptera: Braconidae), and its host, Myzus persicae (Homoptera: Aphididae). Biol Control, 50:324-328.

St. Leger, R.J.; Allee, L.L.; Mai, B.; Staples, R.C. and Roberts, D.W. 1992. Worldwide distribution of genetic variation among isolates of Beauveria spp. Mycol. Res., 96:1007-1115.

Stumpf, N. and Nauen, R. 2001. Cross-resistance, inheritance, and biochemistry of mitochondrial electron transport inhibitor-Vapcomic resistance in (Acari: Tetranychidae). J. Econ. Entomol., 94:1577-1583.

Stumpf, N. and Nauen, R. 2002. Biochemical markers linked to abamectin resistance in Tetranychus urticae (Acari: Tetranychidae). Pestic Biochem Physiol., 72:111-121.

Swirski, E.; Amitai, S. and Dorzia, N. 1967. Laboratory studies on the feeding, development and reproduction of the predacious mites Amblyseius rubini Swirski and Amitai and Amblyseius swirskii Athias (Acarina: Phytoseiidae) on various kinds of food substances. Israel J. Agri. Res., 17: 101-119.

Van der Geest, L.P.S.; Elliot, S.L.; Breeuwer, J.A. and Beerling, E.A.M. 2000. Diseases of mites. Exp. \& Appl. Acarology, 24: 497-560.

van Houten, Y.M.; Hoogerbrugge, H. and Bolckmans, K.J.F. 2007. Spider mite control by four phytoseiid species with different degrees of polyphagy. IOBC/wprs Bulletin, 30(5): 123-127.

van Houten, Y.M.; Ostilie, M.L.; Hoogerbrugge, H. and Bolckmans, K. 2005. Biological control of western flower thrips on sweet pepper using the predatory mites Amblyseius cucumeris, Iphiseius degenerans, A. andersoni and A. swirskii. IOBC/wprs Bulletin, 28(1): 283-286.

Van Leeuwen, T.; Van Pottelberge, S. and Tirry, L. 2006. Biochemical analysis of a chlorfenapyrselected resistant strain of Tetranychus urticae Koch. Pest Manag. Sci., 62:425-433.

van Leeuwen, T.; Vontas, J.; Tsagkarakou, A.; Dermauw, W. and Tirry, L. 2010. Vapcomic resistance mechanisms in the two spotted spider mite Tetranychus urticae and other important Acari; a review. Mol. Biol., 40:563-572.

Van Lenteren, J.C. and Woets, J. 1988. Biological and integrated pest control in greenhouses. Ann. Rev. Entomol., 33:239-269.

Van Pottelberge, S.; Van Leeuwen, T.; Khajehali, J. and Tirry, L. 2009. Genetic and biochemical analysis of a laboratory-selected spirodiclofenresistant strain of Tetranychus urticae Koch (Acari: Tetranychidae). Pest Manag. Sci., 65:358366.

Van Pottelberge, S.; Van Leeuwen, T.; Nauen, R. and Tirry, L. 2008. Resistance mechanisms to mitochondrial electron transport inhibitors in a field-collected strain of Tetranychus urticae Koch (Acari: Tetranychidae). Bull. Entomol. Res., 1:19.

Wekesa, V.W.; Knapp, M.; Maniania, N.K. and Boga, H.I. 2006. Effects of Beauveria bassiana and Metarhizium anisopliae on mortality, fecundity and egg fertility of Tetranychus evansi. J. Appl. Entomol., 130: 155-159.

Wright, J.E. and Kennedy, G.G. 1996. A new biological product for control of major greenhouse pests. In: Proceeding of Brighton Crop Protection Conference- Pest \& Diseases., 3: 885-892. 